Annales de la Société entomologique de France (N.S.) International Journal of Entomology

\title{
New data and taxa for Orthoptera Tettigoniidae and Acrididae from tropical Africa
}

\section{Bruno Massa}

To cite this article: Bruno Massa (2017): New data and taxa for Orthoptera Tettigoniidae and Acrididae from tropical Africa, Annales de la Société entomologique de France (N.S.), DOI: 10.1080/00379271.2017.1334586

To link to this article: http://dx.doi.org/10.1080/00379271.2017.1334586

$$
\text { 曲 Published online: } 17 \text { Aug } 2017 .
$$

Submit your article to this journal

Q View related articles $₫$

View Crossmark data $\asymp$ 


\title{
New data and taxa for Orthoptera Tettigoniidae and Acrididae from tropical Africa
}

\author{
Bruno Massa* \\ Department of Agricultural, Food and Forest Sciences, University of Palermo, Viale Scienze Bd 4A, 90128 Palermo, Italy
}

(Accepté le 16 mai 2017; publié en ligne le 17 août)

\begin{abstract}
Summary. The results of a long-term study on the Orthoptera collected in tropical Africa and preserved in different European natural history museums are reported. Horatosphaga bazeletae $\mathbf{n}$. sp. is described from South Africa, Dapanera falxcercata $\mathbf{n}$. sp. from Cameroon, Eurycorypha specularia n. sp. from Zambia (Tettigoniidae Phaneropterinae), and Eucoptacra popovi n. sp. (Acrididae Coptacrinae) from the Gabon. Furthermore, the new genus Pigalua n. gen. is described for Eulioptera insularis Ragge, 1980 from Annobón Is. (Equatorial Guinea). The new tribe Kevaniellini n. trib. is proposed for Kevaniella bipunctata Chopard, 1954. Besides, the hitherto unknown males of Eurycorypha flavescens (Walker, 1869) and Eurycorypha klaptoczi Karny, 1917 from West Africa are described. In addition, new records or unknown taxonomical characters are reported for five species of Horatosphaga, Peronura clavigera Karsch, 1889, Prosphaga splendens Ragge, 1960, Kevaniella bipunctata Chopard, 1954, Eurycorypha prasinata Stål, 1874, Poreuomena lamottei Chopard, 1954, Tylopsis fissa Ragge, 1964, Catoptropteryx extensipes Karsch, 1896 and Mangomaloba latipennis Chopard, 1954 (Tettigoniidae Phaneropterinae).
\end{abstract}

Résumé. Nouvelles données et nouveaux taxa pour des Orthoptères Tettigoniidae et Acrididae d'Afrique tropicale. Les résultats de l'étude de nombreux Orthoptères collectés en Afrique tropicale et conservés dans divers musées européens, sont présentés. Les nouvelles espèces suivantes sont décrites : Horatosphaga bazeletae n. sp. d'Afrique du Sud, Dapanera falxcercata n. sp. du Cameroun, Eurycorypha specularia n. sp. de Zambie (Tettigoniidae Phaneropterinae), et Eucoptacra popovi n. sp. (Acrididae Coptacrinae) du Gabon. Le genre Pigalua n. gen. est créé pour Eulioptera insularis Ragge, 1980 de l'île d'Annobon (Guinée équatoriale). Une nouvelle tribu, Kevaniellini n. trib., est proposée pour le taxon africain Kevaniella bipunctata Chopard, 1954. Les mâles jusqu'ici inédits d'Eurycorypha flavescens (Walker, 1869) et E. klaptoczi Karny, 1917, espèces d'Afrique de l'Ouest, sont décrits. Enfin, de nouvelles données de répartition et des caractères morphologiques jusqu'ici ignorés sont apportés pour cinq espèces du genre Horatosphaga, ainsi que pour les espèces suivantes de Tettigoniidae Phaneropterinae : Peronura clavigera Karsch, 1889, Prosphaga splendens Ragge, 1960, Kevaniella bipunctata Chopard, 1954, Eurycorypha prasinata Stål, 1874, Poreuomena lamottei Chopard, 1954, Tylopsis fissa Ragge, 1964, Catoptropteryx extensipes Karsch, 1896 et Mangomaloba latipennis Chopard, 1954.

http://www.zoobank.org/urn:lsid:zoobank.org:pub:4A87893D-654C-4EDF-B2A3-FEA9940C4948

Keywords: taxonomy; tropical Africa; new taxa; new records

The present knowledge of taxonomical diversity of some orders or families of insects is still insufficient for tropical Africa and surroundings islands. Tropical forest canopy is known as one of the most diversified environments, which holds many ecological niches where numerous species of insects and other animals have adapted and evolved (Malhi et al. 2013). Some of them live only at welldefined layers of the vegetation and may be detected only by chance during entomological surveys (e.g. by the light that attracts them during the night). The tropical forest region of Central and West Africa, also known as the Guineo-Congolian region, is the second largest tropical forest of the world, with $89.3 \%$ of the total forest surface in Central and 6.0\% in West Africa (Malhi et al. 2013). Due to the large diversity of habitats, tropical Africa is a land where a high number of species of grasshoppers and katydids underwent multiple episodes of speciation. Natural history museums take care of huge numbers of specimens collected during zoological expeditions to unexplored and remote regions in Africa; to date only a portion of this material has been studied, and much work is still waiting. Even if research and collecting have been carried out since the 1800 , much work is still required to have a sufficient knowledge both in taxonomical and distributional terms. Everyone who has the possibility to visit natural history museums to study insects is surprised by the high number of unidentified specimens, probably belonging to undescribed taxa. The present paper reports on some new or little known taxa of specimens preserved in different European museums; results show the importance of these public collections, the low level of knowledge of some systematic groups and the scientific potential to investigate the different and numerous evidences of the biodiversity mosaic.

\footnotetext{
*Corresponding author. Email: bruno.massa@unipa.it
} 


\section{Material and methods}

Specimens from the following museums and collections were included in this study:

MSNG, Museo Civico di Storia Naturale 'G.Doria', Genoa, Italy MSNM, Museo Civico di Storia Naturale, Milan, Italy

MZUF, Museo di Zoologia 'La Specola', University of Florence, Italy

NHM, The Natural History Museum, London, UK

NMHP, National Museum Natural History, Prague, Czech Republic

NMW, Naturhistorisches Museum, Vienna, Austria

BMCP, Bruno Massa Collection, University of Palermo, Italy

Some specimens were photographed with a Nikon Coolpix 4500 digital camera (Japan), mounted on a Wild M5 Stereomicroscope (Germany), and photos were integrated using the freeware CombineZP (Hadley 2008). Mounted specimens were measured with a digital calliper (precision $0.01 \mathrm{~mm}$ ); the following measurements were taken (all in mm). Body length: dorsal length from the head to the apex of the abdomen, ovipositor excluded in females; pronotum length: length of the pronotum along dorsal median line; hind femur: length of hind femur; tegmina: length and maximum width of tegmina; ovipositor: maximum length (the curvature of the ovipositor is not considered, the measurements were taken from the subgenital plate to the tip of the ovipositor).

Collecting authorizations are reported in the acknowledgements.

\section{Results}

Family Tettigoniidae Krauss, 1902 Subfamily Phaneropterinae Burmeister, 1838 Tribe Acrometopini Brunner von Wattenwyl, 1878

Horatosphaga inclusa (Karsch, 1893)

(Figure 1A, 1C, 1E, 1F, 1K, 1L)

Material examined. Ivory Coast, Dabakala [8¹2'4.94”'N 04²3'33.14”'W], 242 m, 22-27.V.2015 (UV) $\left(1\right.$ ㄱ) (BMCP); Ivory Coast, Mt. Tonkoui [07²7'15.2”'N $07^{\circ}$ 38'12.5’W], 1200 m, 30.XI.2015 (UV) (1ð) (BMCP).

Remarks. Horatosphaga inclusa has the 10th male abdominal tergite very stout and variable and may be confused with $H$. crosskeyi Ragge, 1960. There are differences in the stridulatory file; in $H$. inclusa it is curved, $1.4 \mathrm{~mm}$ long, and consists of c.100 teeth, of which the central ones are higher than the others (Figure 1A); the stridulatory file of $H$. crosskeyi is similar, $1.4 \mathrm{~mm}$ long, and consists of c.100 teeth, of which the distal ones are higher than the others (Figure 1B). Other differences lie in the apical part of the 10th male tergite, that in lateral and dorsal views in H. inclusa is thicker, while in $H$. crosskeyi it is thinner (Figure 1C, 1D, 1E, 1G); the subgenital plate of $H$. inclusa is apically diverging and has a wide v-shaped concavity (Figure $1 \mathrm{~F}$ ), while that of $H$. crosskeyi is more or less rectangular and ends with a narrower concavity (Figure 1H). H. inclusa and $H$. crosskeyi are undoubtedly morphologically closely related; however, the differences in the stridulatory file result in different songs, and this is an important specific barrier.
Distribution. Previously recorded from Ghana and Togo, here reported also from the Ivory Coast; records of $H$. crosskeyi from the Ivory Coast [Massa 2016; Comoe, Kolomabira and Zamou (4 $\hat{\sigma}, 1$ o)] have to be identified as $H$. inclusa (see H. crosskeyi); it is a new record from Ivory Coast.

\section{Horatosphaga crosskeyi Ragge, 1960 (Figure 1B, 1D, 1G, 1H)}

Material examined. Cameroon, National Park Benoué, Camp. Buffle Noir 21.XI.2006, S. Vanni \& A. Nistri

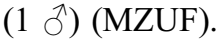

Distribution. Horatosphaga crosskeyi is new to Cameroon; this species was described from Nigeria (Ragge 1960a). Later, it has been recorded from Senegal (Ragge \& Roy 1961) while records from the Ivory Coast (Massa 2016) have to be referred to $H$. inclusa (see above).

\section{Horatosphaga heteromorpha (Karsch, 1889) (Figure 1M)}

Material examined. Somalia, Giumbo $\left[0^{\circ} 14^{\prime} \mathrm{N} 42^{\circ} 37^{\prime} \mathrm{E}\right]$ 1909, G. Ferrari (1 §) $(\mathrm{MSNG})$; Somalia, Giuba, Uabi Mana II.1911, C. Citerni (1 đ) (MSNG); Ethiopia, Bass Narok (= Lake Turkana) VIII-IX.1896, V. Bottego (1 o) (MSNG); Somalia, El Ellan, Ceel Cellan I.1968, Funaioli (1 ふ) (MZUF).

Remarks. The stridulatory file of $H$. heteromorpha consists of $c .90$ teeth, $1.5 \mathrm{~mm}$ long, with a conspicuously raised group of c.20 teeth in distal part, and another, less high, of c. 10 teeth in central part (Figure 1M).

Distribution. From savannah grass- and bushlands to forest edge and forest clearings in the montane zone of East Africa (Hemp 2013).

\section{Horatosphaga concava Ragge, 1960 (Figure 1I, 1J)}

Material examined. Democratic Republic of Congo, Upper Uele, Kapili V.1927, F.S. Patrizi (1ठ̋) (MSNG).

Remarks. The male of Horatosphaga concava is characterized by two swollen apices on the $10^{\text {th }}$ abdominal tergite (Figure 1I). The stridulatory file is also very peculiar: it consists of $c .80$ teeth, $c .1 .4 \mathrm{~mm}$ long, of which $c .50$ in the proximal part are closely spaced, while c.30 in the distal part are more widely spaced (Figure 1J).

Distribution. Previously known from Sudan and Kenya (Hemp 2006), new to Democratic Republic of Congo. 

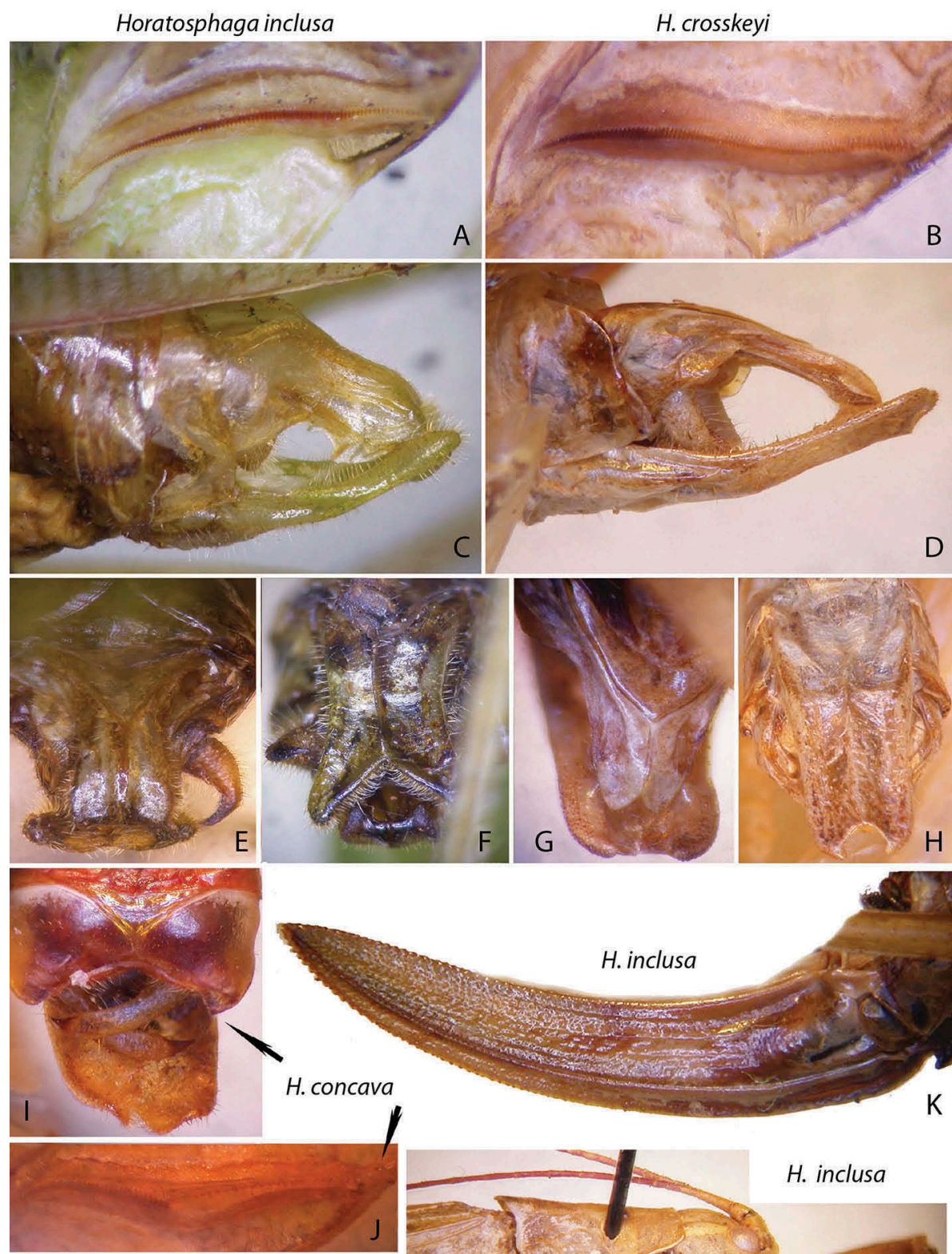

H. heteromorpha
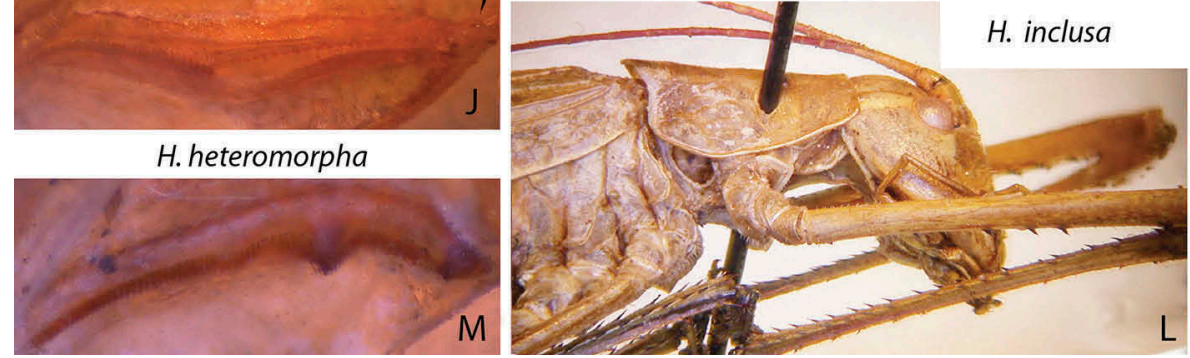

Figure 1. Horatosphaga spp. A, B, ô, stridulatory files: A, H. inclusa (Karsch); B, H. crosskeyi Ragge. C, D, ô, lateral view of last abdominal segments: $\mathbf{C}, H$. inclusa; $\mathbf{D}, H$. crosskeyi. $\mathbf{E}, \mathbf{F}, H$. inclusa, $\widehat{\jmath}$ : $\mathbf{E}$, dorsal view of last tergite; $\mathbf{F}$, subgenital plate. $\mathbf{G}, \mathbf{H}, H$.

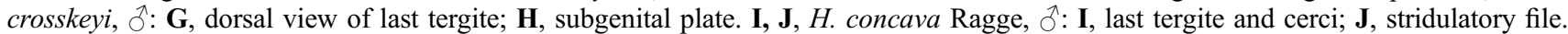

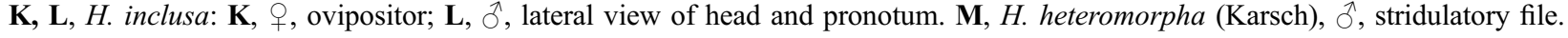

\section{Horatosphaga leggei (Kirby, 1909)}

Material examined. Uganda, Entebbe $\left[3^{\circ} 00^{\prime} \mathrm{N} 32^{\circ} 28^{\prime} \mathrm{E}\right]$ 1907, C. Berti (1 $\left.{ }^{\top}\right)$ (MSNG); Uganda, Thoro 1909, C.

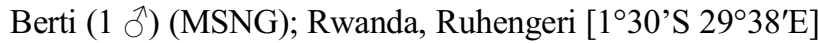

\section{VIII.1994, L. Bartolozzi (1 ठ̂) (MZUF).}

Distribution. Montane areas of East Africa to Democratic Republic of Congo (Ragge 1960a; Hemp 2006; Massa 2015b). 

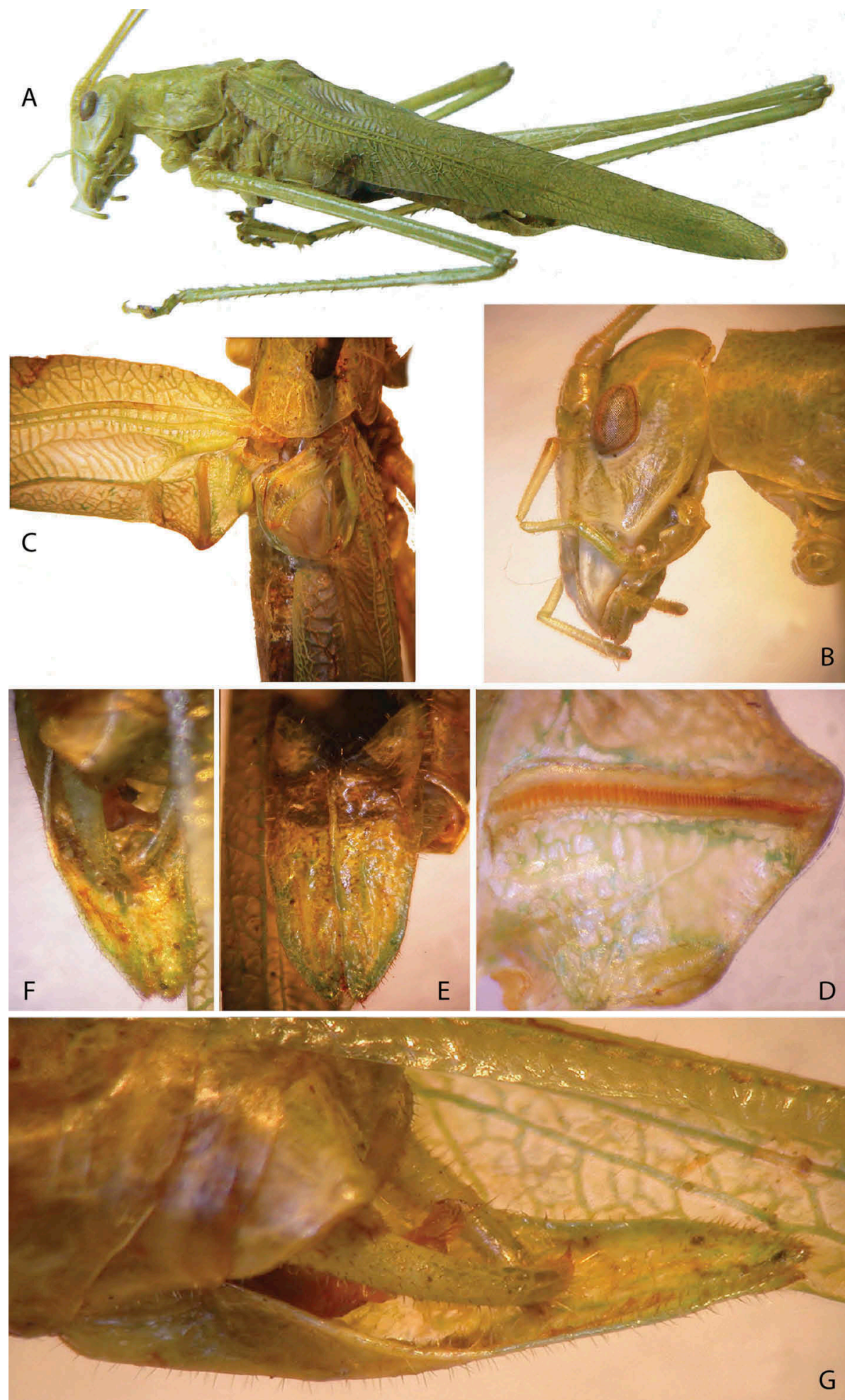

Figure 2. Horatosphaga bazeletae n. sp. A, Habitus in lateral view. B, Head in lateral view. C, Stridulatory area of the left and right tegmina. D, Stridulatory file of left tegmen. E, Ventral view of subgenital plate. F, Subgenital plate and cerci from above. G, Lateral view of subgenital plate and cerci. 
Horatosphaga bazeletae n. sp. (Figures 2A-4G)

Type material. Holotype: $\hat{\sigma}$, South Africa, Transvaal, Pretoria [2545'S 28¹4'E] 1.I.1983, G. Costa (Coll. M. La Greca, MSNM).

Description of male. Uniformly green (Figure 2A).

Fastigium of vertex sulcate, fastigium of frons pointed, extending upwards beyond fastigium of vertex. Eyes oval (Figure 2B), c.1/3 of the length of the head.
Pronotum smooth without lateral carinae.

Tegmina narrow, much longer than body length, but no longer than flexed hind knees, about 7.3 times longer than broad. Alae reduced to small scales. Stridulatory area of left and right tegmina illustrated in Figure 2C. Stridulatory file, $0.8 \mathrm{~mm}$ long, consists of c.80 teeth more and more close from distal to proximal area (Figure 2D).

Fore legs missing on holotype. Mid and hind femora unarmed, mid tibiae with 11 inner and 13 outer ventral and
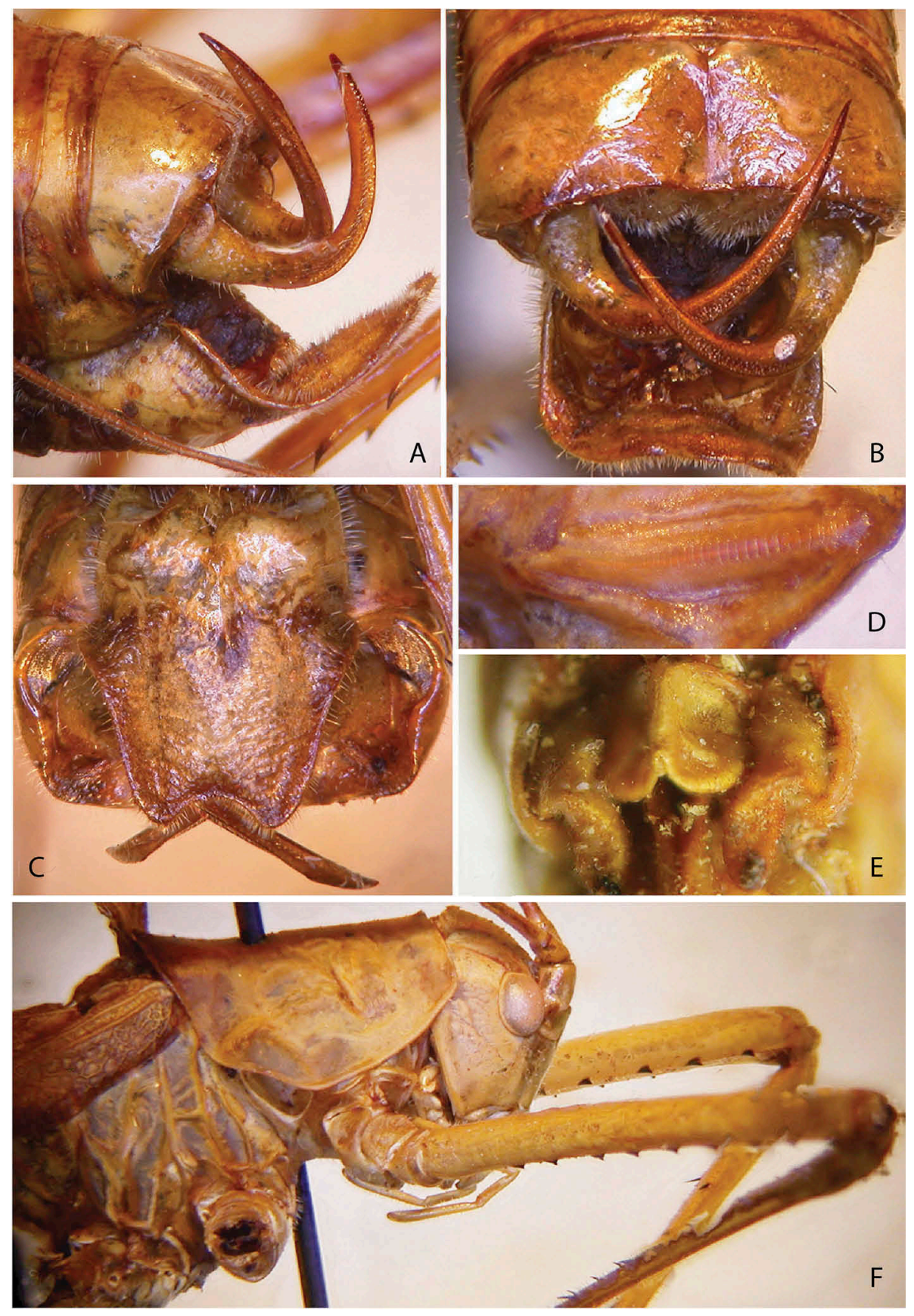

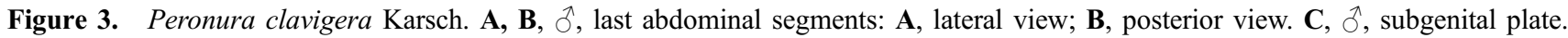
$\mathbf{D}, \hat{o}$, stridulatory file. E, + , subgenital plate. $\mathbf{F}, \hat{o}$, lateral view of head and pronotum. 
dorsal spines +1 spur on each side, hind tibiae with 5 ventral inner and outer spines +1 spur on each side, and 10 dorsal inner and outer spines +1 spur on each side.

Cerci stout, incurved and apically pointed (Figure 2F, $2 \mathrm{G})$. Subgenital plate long and concave, apically converging with two apices separated by a very narrow concavity (Figure 2E, 2F, 2G). Styli absent.

Female. unknown.

Measurements. Body length: 20.5; length of pronotum: 4.1; height of pronotum: 1.8; width of pronotum: 2.2; length of tegmina: 22.0; width of tegmina: 3.0 ; length of hind femur: 22.2 .

Etymology. This species is dedicated to Corinna Bazelet, for her contribution to the conservation of Orthoptera in South Africa.

Remarks. According to Ragge (1960a, 1961), the genera Horatosphaga and Lamecosoma Ragge, 1960 are closely related and both may have the body very attenuate and may lack posterior wings. However, while Lamecosoma has femora armed with small spines, Horatosphaga has femora unarmed. The genus Horatosphaga is widely distributed in tropical Africa; Lamecosoma is currently known from Kenya, Rhodesia, Zambia and Tanzania (Ragge 1960a, 1961; Hemp 2002, 2006, 2013). The specimen from South Africa has characteristics that generally lie in the variation of the genus Horatosphaga, but the remarkable attenuation of its body is reminiscent of the genus Lamecosoma; however, the eyes are oval, while in Horatosphaga and Lamecosoma they are rounded. Nevertheless, it is here described as a new species tentatively belonging to the genus Horatosphaga.

Affinities. $H$. bazeletae n. sp. is related to two species of Horatosphaga lacking posterior wings, H. meruensis (Sjöstedt, 1910) from Tanzania and H. nuda Ragge, 1960 from Sudan. It differs from both in the subgenital plate (longer) and cerci (shorter) and in the venation of right and left tegmina (cf. figures 31 and 32 of Ragge 1960a and photographs in Cigliano et al. 2016). Additionally, Hemp
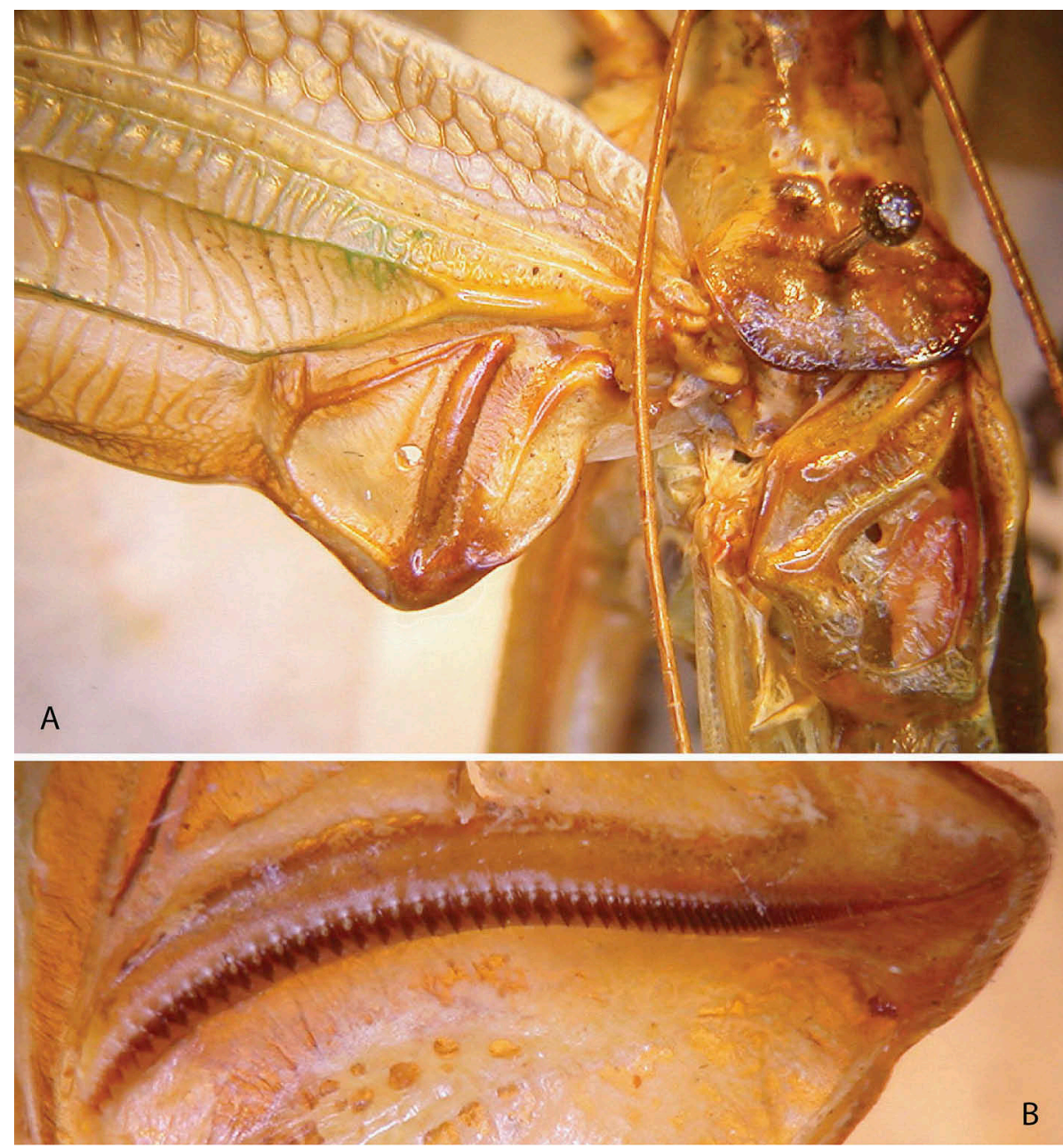

Figure 4. Prosphaga splendens Ragge, ठิ. A, Dorsal view of stridulatory area. B, Stridulatory file. 

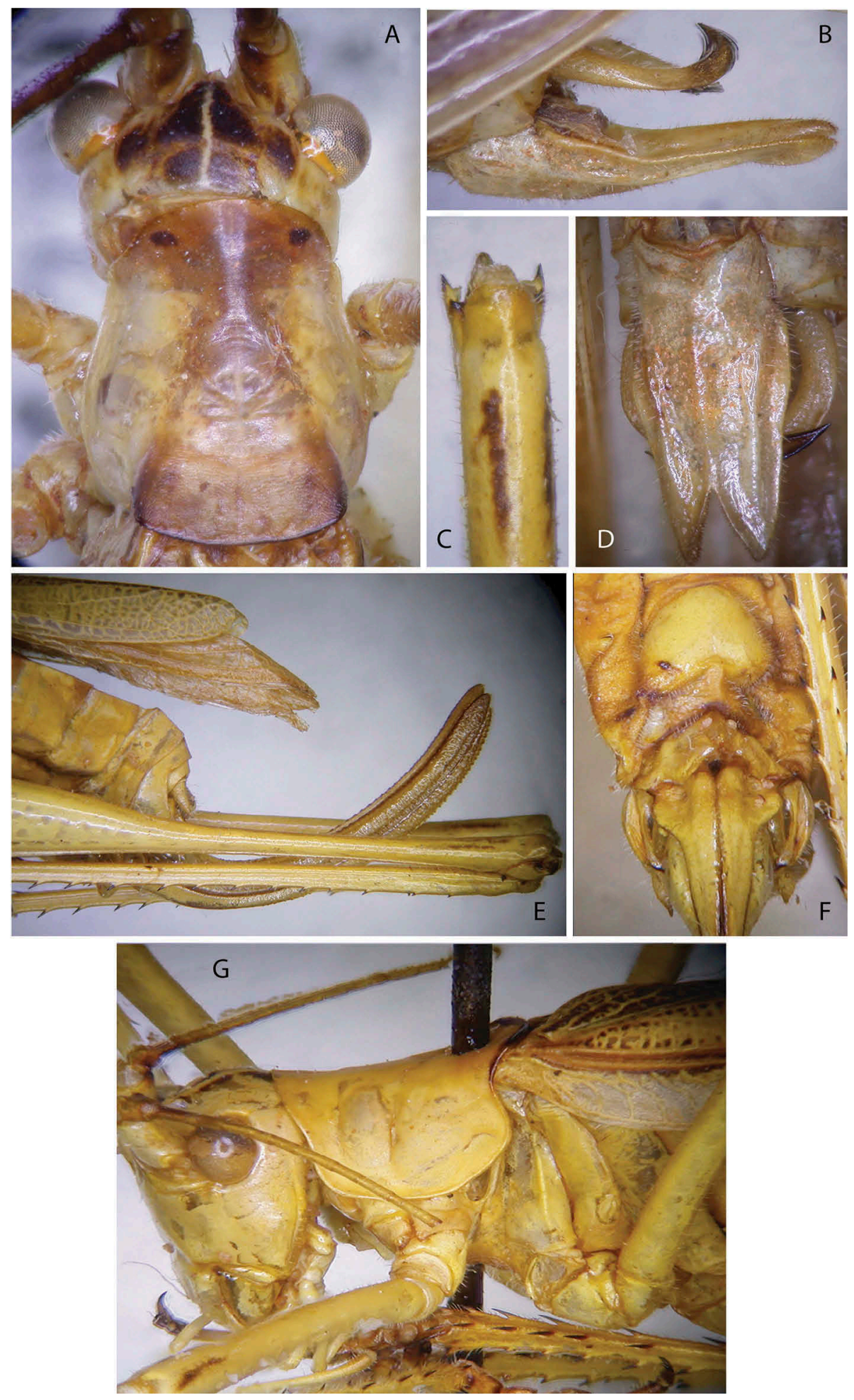

Figure 5. Kevaniella bipunctata Chopard. A, ô, dorsal view of head and pronotum. B, $\hat{\jmath}$, lateral view of last abdominal segments. C, $\hat{\sigma}$, spines on genicular lobes of hind legs. D, $\hat{\partial}$, subgenital plate. E,,+ , lateral view of ovipositor. F, $q$, subgenital plate. G, $\hat{\partial}$, lateral view of head and pronotum.

(2007) described the fragile and slender $H$. tenera with reduced hind wings; she considered it related to $H$. meruensis and $H$. nuda. The male of $H$. tenera has also a shorter subgenital plate compared to that of $H$. bazeletae. Finally $H$. bazeletae has eyes more oval than the previous and other species of Horatosphaga. 

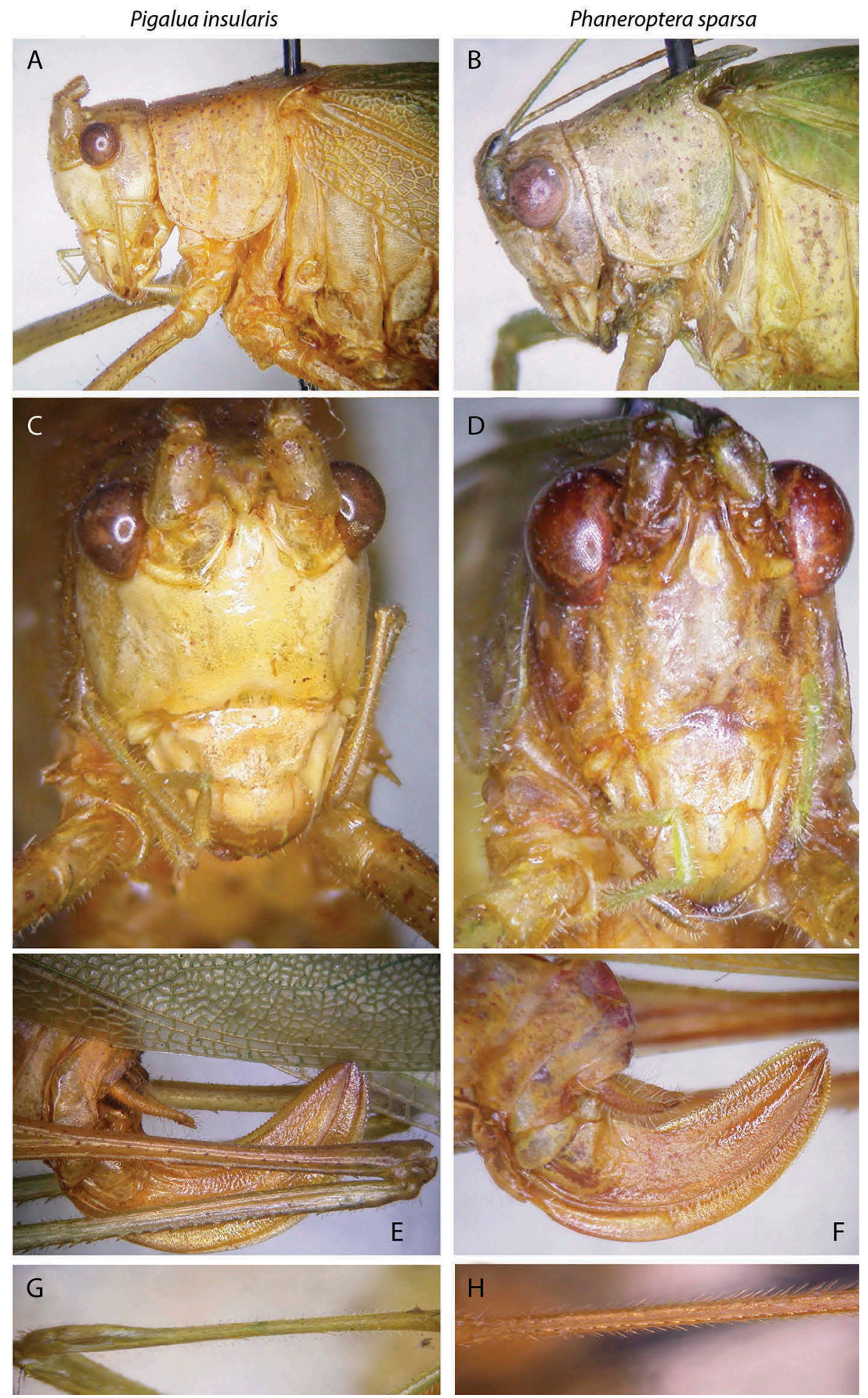

Figure 6. Comparison of Pigalua insularis (Ragge, 1980) with Phaneroptera sparsa Stål, 1857. A, B, đ̂, lateral view of head and pronotum. $\mathbf{C}, \mathbf{D}, \widehat{O}$, face. $\mathbf{E}, \mathbf{F},+$ ovipositor. $\mathbf{G}, \mathbf{H}$, dorsal view of fore tibia.

Distribution. Known only from Transvaal, South Africa.

Note on the species of the genus Lamecosoma. According to the art. 31.2 of the ICZN (2012, Agreement in gender), "A species-group name, if it is or ends in a Latin or Latinized adjective or participle in the nominative singular, must agree in gender with the generic name with which it is at any time combined". Lamecosoma is composed of $\lambda \alpha$ (from Greek: 
prefix with intensive force), $\mu\rceil \kappa \circ \varsigma$ (from Greek: length) and $\sigma \omega \mu \alpha$ (from Greek: body, neuter); thus, the name Lamecosoma is neuter and consequently the name of species, being adjective, must agree with it: Lamecosoma tenue and Lamecosoma inerme [not tenuis and inermis, as in the original descriptions of Ragge (1960a, 1961)].

\section{Peronura clavigera Karsch, 1889 (Figure 3A-3F)}

Material examined. Kenya, Taita District, surroundings of Voi [0323'49”S 38³3'12’E], 30.V-2.VI.1994, L. Bartolozzi, B. Cecchi, A. Sforzi (1 §) (MZUF); Kenya, Embu District, Siakago [0³5'33”S 37³8'33”E], I.1996 (2 ㅇ) (MSNG); Kenya, Embu District, Nguthi [0³5'12’S 3744'34”E], 28. II.1998 (1) (MSNG).

Remarks. Peronura clavigera is the only brachypterous representative of the genus (Figure $3 \mathrm{~F}$ ), characterized by its peculiar male genitalia (Figure $3 \mathrm{~A}-3 \mathrm{C}$ ) and female subgenital plate (Figure 3E). The stridulatory file is very reduced and consists of $c .50$ teeth, of which at least 30 on the distal part are more widely spaced than in the proximal part (Figure 3D).

Distribution. Tanzania and Kenya (Ragge 1960a; Hemp 2013).

\section{Prosphaga splendens Ragge, 1960 (Figure 4A, 4B)}

Material examined. Somalia, Bud bud $\left[04^{\circ} 39^{\prime} 26^{\prime \prime} \mathrm{N} 46^{\circ}\right.$ 56'25'’E] 28.XI-4.XII.1982 (3 §) (MSNG).

Remarks. Prosphaga splendens has characteristic raised stridulatory areas both in the left and right tegmina (Figure 4A); the stridulatory file, c.2.2 mm long, consists of $c .80$ teeth, more widely spaced in the proximal part and closed spaced in the distal one (Figure 4B).

Distribution. Ragge (1980) described P. splendens from specimens collected at Werder (East Ethiopia)

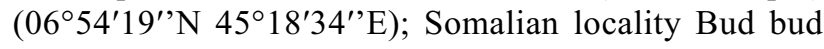
is not far from Werder $(c .300 \mathrm{~km})$.

Tribe Kevaniellini n. trib.

Type genus. Kevaniella Chopard, 1954.

When Chopard (1954a) described the genus Kevaniella, he highlighted that its sole representative $K$. bipunctata was a rather extraordinary insect difficult to place systematically. He suggested that Pardalotini Brunner von Wattenwyl, 1878 could be possible relatives. Ragge (1980) was also unable to find relatives in the subfamily Phaneropterinae. The genus Kevaniella indeed has very peculiar characters that justify the description of a new tribe for it.
Characters of the Kevaniellini n. trib. are the following: general shape slender with long legs, fastigium of vertex narrow not contiguous with fastigium of frons, eyes rounded, globular (Figure 5A), pronotum longer than high with the insertion on the disc rounded (Figure 5G), coxae unarmed, femora unarmed, tibiae armed superiorly and inferiorly, tympana of fore tibiae open, oval, all the genicular lobes armed with an evident spine (Figure 5C), ovipositor long, narrow, gently upcurved (Figure 5E, 5F).

\section{Kevaniella bipunctata Chopard, 1954 (Figure 5A-5G)}

Material examined. Somalia, El Ellan, Ceel Cellan 24. XI-4.XII.1985 (1 §̂) (MZUF); Somalia, Guddo, road to Baled 23.VI.1984, L. Bartolozzi (1 ㅇ) (MZUF).

Remarks. Figure 5A-5G present some characters in the male and female of this peculiar species.

Distribution. Known from Kenya (Chopard 1954a), Ethiopia and Somalia (Ragge 1980).

Tribe Phaneropterini Burmeister, 1838

Pigalua n. gen. (Figure 6A, 6C, 6E, 6G)

Type species. Eulioptera insularis Ragge, 1980, here designated.

Description. Head. Fastigium of vertex narrow and pointed, not contiguous with the fastigium of frons, much narrower than the first antennal segment. Eyes round, small, moderately prominent, $c .1 .5$ times as long as the subocular groove, and as wide as the retroocular space (Figure 6A). Scapus placed within an area with raised margins and a bit narrower than the eye. Face without fronto-genal carinae below antennae (Figure 6C).

Thorax. Pronotum longer than high, humeral excision not very deep (Figure 6A).

Legs. Fore coxae armed with a spine, fore tibiae rounded, not furrowed superiorly (Figure 6G), fore femora with ventral spines, fore tibiae with ventral spines, open tympanum on inner and on outer sides. Mid femora and tibiae with ventral spines. Hind femora with ventral spines, hind tibiae with ventral spines and only 1 apical spur.

Tegmina well developed, slightly shiny and a bit shorter than hind wings.

Ovipositor gently up-curved, 2.4 times longer than pronotum (Figure 6E).

Diagnosis. Pigalua n. gen. is vaguely similar to Phaneroptera Serville, 1831 and Eulioptera Ragge, 1956, mainly in the general shape. Some characters of this taxon, such as rounded, not furrowed upper side of fore legs, small eyes, tibiae with only 1 apical spur, and ovipositor longer than pronotum, are not present in any 
Phaneroptera and Eulioptera species. However, Phaneroptera and Eulioptera have the upper surface of fore tibiae furrowed (Figure $6 \mathrm{H}$ ), wider and higher eyes (c.0.8-1.0 times as long as subocular groove and much wider than the retroocular space) (Figure 6B, 6D), scapus much smaller than eyes, lateral lobes of pronotum with different shape, a deeper humeral excision (Figure 6B), tegmina distinctly shorter than hind wings, and ovipositor of smaller size and different curvature (Figure 6F). When Ragge (1980) described Eulioptera insularis, he highlighted that it is the sole species of the genus with only 1 apical spur on each side of hind tibiae; other species have 2-3 apical spurs. Within the genus Phaneroptera, only $P$. albida Walker, 1869 has 2 apical spurs, while other species have 3 apical spurs (Ragge 1960b, 1980). Among species with open tympana few genera have fore tibiae not furrowed superiorly (e.g. Parapyrrhicia Brunner von Wattenwyl, 1891, Symmetroraggea Massa, 2015a). Thus, characters of this taxon are exclusive.

Etymology. From autochthonous language: Pigalu = local name of the island Annobón (also known as Pogalu), where this taxon is known for certain (Ragge 1980).

\section{Pigalua insularis (Ragge, 1980) n. comb. (Figure 6A, 6C, 6E, 6G)}

Material examined. Equatorial Guinea, Annobón Is. (= Pigalu) V.1902, L. Fea (1 †) (MSNG).

Remarks. Some additional morphological characters of this species are the following. Yellow-greenish with small reddish dots on the head, pronotum, femora and abdomen. Tegmina green.

Fastigium of vertex narrow and pointed, not contiguous with the fastigium of frons, much narrower than the first antennal segment. Eyes small, round, moderately prominent, c.1.5 times as long as the subocular groove and as wide as the retroocular space (Figure 6C).

Pronotum longer than high, its humeral excision not very deep and not indented anteriorly; lateral lobes rather with straight hind margin and curved ventral margin (Figure 6A).

Fore coxae armed with one small spine, fore femora with 3 spines on inner ventral margin [8-9 according to Ragge (1980)], fore tibiae with open tympana on both sides, superiorly rounded, not furrowed (Figure 6G) with 3 inner ventral spines +1 spur on each side, mid femora with 3 outer spines, mid tibiae with 8 outer ventral spines +1 spur on each side, hind femora with 6 outer and 4 inner ventral spines, hind tibiae with 15 inner and outer ventral spines, and many inner and outer dorsal spines +1 spur on each side.
Tegmina well developed, slightly shiny and a bit shorter than hind wings. In the area of overlapping tegmina, a series of microscopic bristles cover the transverse veinlets of the right tegmen [according to Heller et al. (2015), females of Phaneropterinae have some teeth on the right tegmen to communicate with the other sex].

Ovipositor gently up-curved, 2.4 times longer than pronotum, cerci conical and slender.

Measurements. The female above reported is smaller than that recorded by Ragge (1980), whose measurements are reported in parenthesis. Body length: 20.9 (38.3); pronotum length: 3.8 (4.3); pronotum height: 3.4 ; length of tegmina: 26.6 (26.5); width of tegmina: 5.7; length of hind wings: 32.7 ; length of hind femora: 18.0 (18.7); ovipositor: 9.2 (8.1).

Distribution. Known only from Annobon Is. $\left(17.5 \mathrm{~km}^{2}\right)$, which is $c .350 \mathrm{~km}$ off the West African coast and $180 \mathrm{~km}$ off the island of Sao Tomé.

\section{Tribe Holochlorini Brunner von Wattenwyl, 1878}

$$
\text { Dapanera falxcercata n. sp. (Figure 7A-7E) }
$$

Type material. Holotype: $\hat{\sigma}$, Cameroon, Mundame [0434'26'”N 09³0'25'E], R. Rohde (coll. Brunner von Wattenwyl, NMW). Paratype: 1 q, same data (coll. Brunner von Wattenwyl, NMW).

Description. Male (Figure 7A, 7C, 7D, 7E). Medium sized. Green-yellowish, tympana bordered by black margins.

Head. Fastigium of vertex narrow, furrowed above. Eyes rounded, well projecting.

Legs comparatively long. Fore coxae armed with a well-developed spine. Fore tibiae furrowed on upper margin, distinctly widening above tympanum, which is closed on inner and open on outer side. Fore femora unarmed, fore right tibia with 2 spines (fore left with 3) plus 1 spur on inner margin, outer ventral margin unarmed, 1 spur on outer dorsal margin, mid femora armed with 2 spines on outer ventral margin, mid tibiae with 8 on outer and inner ventral margins, plus 1 spur on each side, hind femora armed with 7 spines on inner and 6 on outer ventral margins, hind tibiae with many spines on ventral and dorsal margins and 3 spurs on each side.

Thorax. Pronotum little narrowing anteriorly, flat above, anterior margin straight, posterior margin widely rounded, humeral sinus evident, lobes of pronotum rounded.

Tegmina comparatively wide with rounded apices. Wings longer than tegmina. Stridulatory region of left tegmen narrow.

Abdomen. 10th tergite with straight hind margin; cerci long, stout, incurved at obtuse angle, thus narrowing, 

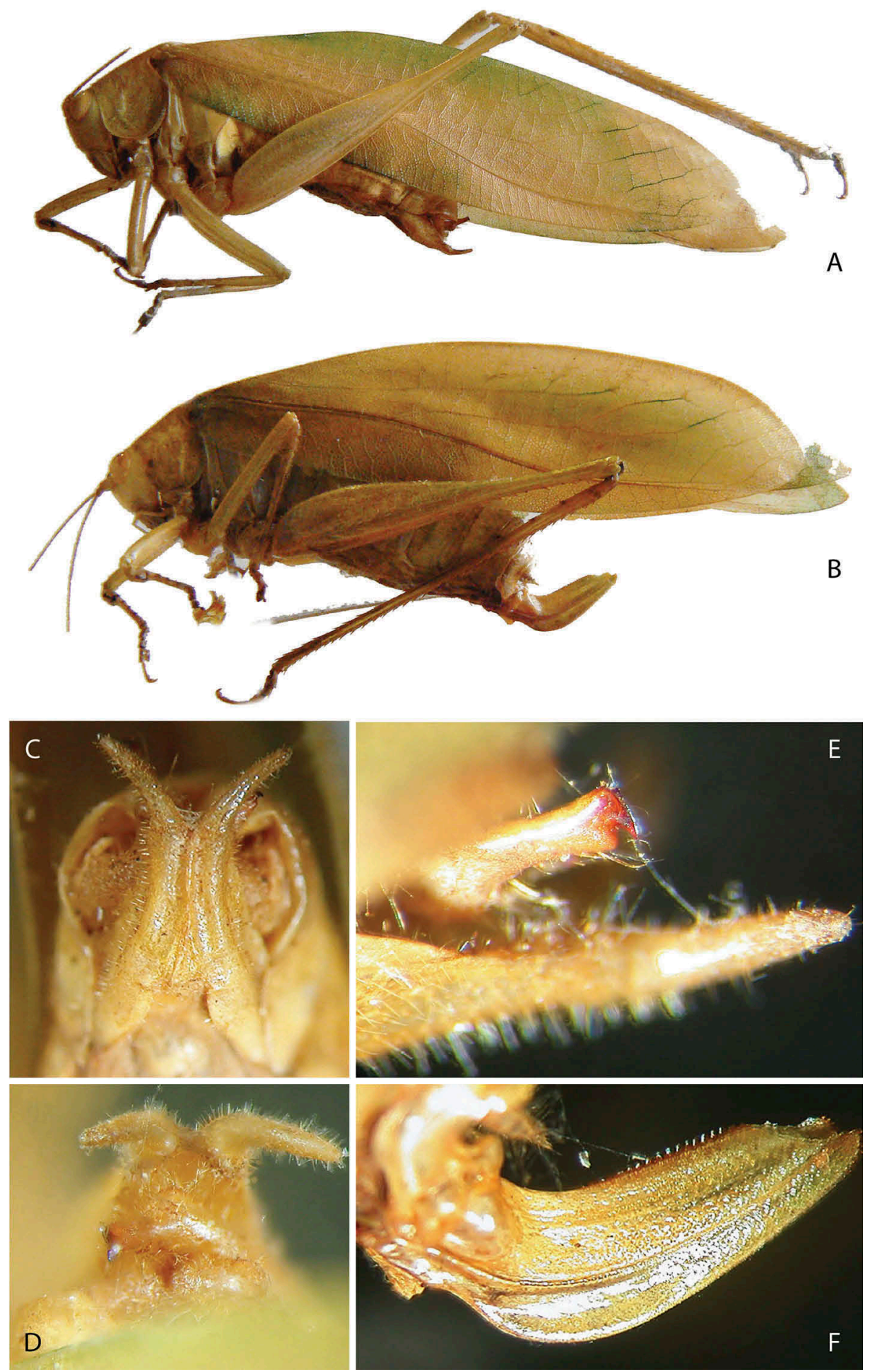

Figure 7. Dapanera falxcercata n. sp. A, B, Habitus: A, $\hat{\jmath} ; \mathbf{B}, \uparrow . \mathbf{C}$, $\hat{\sigma}$, subgenital plate. D, $\hat{\sigma}$, dorsal view of last abdominal segments. $\mathbf{E}, \hat{\jmath}$, cerci. $\mathbf{F}, q$ ovipositor, lateral view.

flattened and with a chitinous black apex ending as a sharp nail, shorter than subgenital plate (Figure 7D, 7E). Subgenital plate long and not divided, with a central keel; styli stout, long and diverging (Figure 7C, 7D).
Female (Figure 7B, 7F). Same characters as the male, with the following differences. Fore femora armed on inner ventral margin with 4 spines, fore tibiae with 4 spines plus 1 spur on inner and outer ventral margins, 1 
spur on outer dorsal margin, mid femora armed with 5 spines on outer ventral margin, mid tibiae with 6 on outer and inner ventral margins, plus 1 spur on each side, hind femora armed with 7-8 spines on outer and inner ventral margins, hind tibiae with many spines on ventral and dorsal margins and 3 spurs on each side. Ovipositor gently up-curved, cerci pointed, subgenital plate triangularly pointed (Figure 7F).

Measurements. Male. Body length: 24.3; pronotum length: 6.3; pronotum height: 5.1; hind femur: 20.8; tegmina: 38.6. Female. Body length: 25.1; pronotum
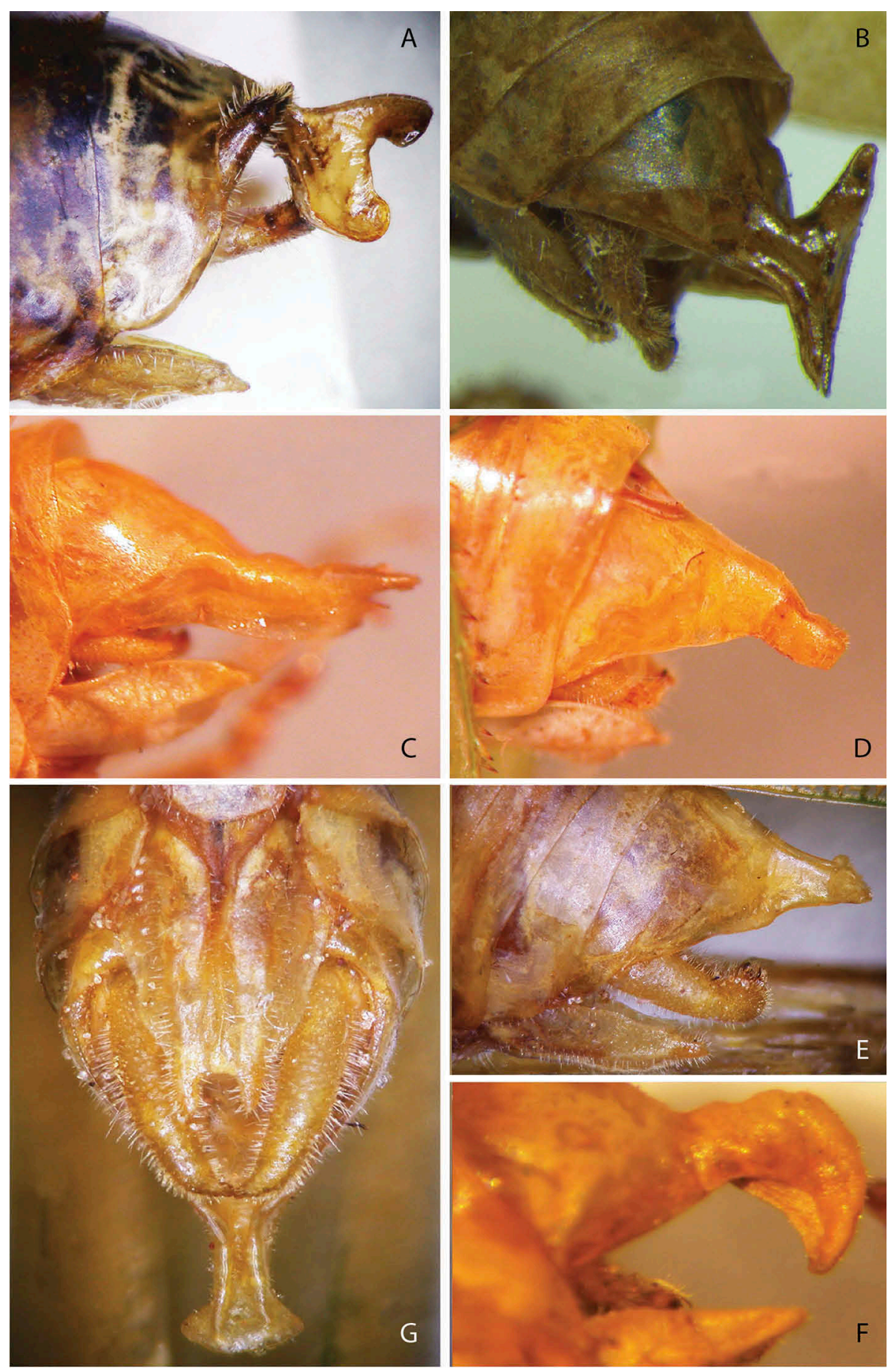

Figure 8. A-F, Lateral view of last abdominal segments of male: A, Eurycorypha klaptoczi Karny; B, E. aequatorialis Krauss; C, E. velicauda Karsch; D, E. securifera Brunner von Wattenwyl; E, E. flavescens (Walker); F, E. combretoides Hemp. G, E. flavescens, subgenital plate and cerci. 
length: 6.0; pronotum height: 5.0; hind femur: 20.2; tegmina: 34.7 ; ovipositor: 6.7 .

Diagnosis. A typical Dapanera, the male is easily distinguished from all other Dapanera by its sickleshaped cerci and long and diverging styli on the subgenital plate.

Etymology. From Latin (with cercus similar to a $f a l x=$ sickle), feminine adjective.

Tribe Amblycoryphini Brunner von Wattenwyl, 1878

\section{Eurycorypha prasinata Stål, 1874}

Material examined. Madagascar, Antalaha $\left[14^{\circ} 54^{\prime} \mathrm{S} 50^{\circ}\right.$ $\left.16^{\prime} \mathrm{E}\right](1$ ㅇ) (NMHP).

Distribution. Known from Madagascar and Comore Is. (Chopard 1958) and reported from various African countries by Karsch (1888), and South Africa by De Saussure (1899).

Eurycorypha flavescens (Walker, 1869)

(Figure 8E, 8G)

Material examined. Ivory Coast, Comoe, Kolomabira (228 m) 11.XI.2014 (UV), P. Moretto (1 đ) (BMPC); Ivory Coast, Boundiali, M' Banto 6-8.VII.2013 (UV), P. Moretto (1 + ) (BMPC); Ivory Coast, Man, Mt. Tonkoui (1200 m) 18.VIII.2015 (UV), P. Moretto (1 §) (BMPC); Ivory Coast Korhogo, Kogo (dry forest) 21.VII.2014 (UV), P. Moretto (1 $\hat{\delta}, 5$ ㅇ) (BMPC); Ivory Coast Korhogo, Kogo village 20.VII.2014 (UV), P. Moretto (1 +) (BMPC); Central African Republic, Ndoki, border of Lake 1 20-23.II.2012 (UV), P. Moretto (1 ㅇ) (BMPC).

Remarks. Eurycorypha flavescens was described by Walker (1869) on a female from Gambia, characterized mainly by the very long ovipositor (as long as the abdomen). Kirby (1906) transferred it to the genus Corycomina Karsch, 1896 and synonymized Corycomina camerata (Karsch, 1888) with Corycomina flavescens (Walker, 1869). Griffini (1908) and Sjöstedt (1912) recorded Corycomina flavescens from Cameroon, but later Ragge (1980) established that Corycomina camerata and Eurycorypha flavescens are two distinct taxa belonging to different genera. This species is very peculiar for its very long ovipositor; thus, studying a series of specimens it was possible to match males and females, discovering after nearly 150 years the male of E. flavescens. E. adicra from Cameroon is the only other species with such a long ovipositor. However, the shape of the ovipositor is different, being strongly up-curved with obtuse tips of the valves (Karsch 1892).
Description of male. Species of medium size. Green, legs yellowish.

Head typical of the genus, eyes oval, fastigium of vertex wide, ca. three times as wide as scapus. Frontogenal carinae not much developed. Antennae long, scapus green, remaining part yellow.

Pronotum flat, concave on the anterior margin and with rounded posterior margin. Lateral carinae distinct, humeral excision well-developed, integuments smooth.

Both pairs of wings well-developed. Tegmina oval, rounded at tips, about 2.7-2.8 times longer than wide. Hind wings longer than tegmina.

Fore coxae armed, fore tibiae with open tympana, fore femora with 3 inner ventral spines, fore tibiae with 4-5 spines on inner and on outer ventral margins; mid femora with 1-2 outer ventral spines, mid tibiae with 4 inner and outer ventral spines; hind femora with 4-5 inner and outer ventral spines.

Last abdominal tergite modified, ending with a protruding appendix, whose surface is superiorly sulcate, with enlarged spoon-shaped apex, cerci stout and incurved, with two apical chitinous teeth (Figure 8E). Styli absent, subgenital plate long, narrow, with an apical concavity and two appendices similar to styli (Figure 8G).

Affinities. Males of Eurycorypha securifera Brunner von Wattenwyl, 1878 are most similar to those of E. flavescens. Differences are the following: last tergite laterally compressed with a cut and axe-shaped apex, cerci short with cut apex, subgenital plate wide, apically rounded with very small styli (Brunner Von Wattenwyl 1878). Other related species are illustrated in Figure 8A-8D, 8F, 9A-9G.

Distribution. Previously known only from Gambia, Eurycorypha flavescens is here reported for the first time from Ivory Coast and Central African Republic; thus, its distribution covers central-western Africa.

\section{Eurycorypha klaptoczi Karny, 1917 (Figure 8A)}

Material examined. Burkina Faso, Pama $\left[11^{\circ} 14^{\prime} \mathrm{N} 0^{\circ} 43^{\prime} \mathrm{E}\right]$ VIII.2005, P. Moretto (4 ठ) (BMPC); Ivory Coast, Tiené (671 m) 8.VII.2013 (UV), P. Moretto (1 ð) (BMPC); Ivory Coast, Boundiali, M' Banto 6-8.VII.2013 (UV), P. Moretto (2 ô, 1 क) (BMPC); Ivory Coast, Bondoukou Zamou

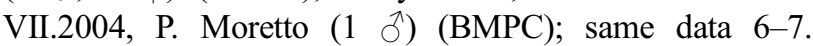
VI.2015 (UV), P. Moretto (2 +) (BMPC); same data 10. IV.2016 (1 ㅇ) (BMPC); Ivory Coast, Comoe, Kolomabira (228 m) VII.2015 (UV), P. Moretto (1 $\jmath^{2}, 4$ +) (BMPC); Ivory Coast, Korhogo, Kogo (dry forest) 23.VII.2014 (UV), P. Moretto (1 ¿) (BMPC); Ivory Coast, Man, Mt. Tonkoui (1200 m) 18-20.VI.2015 (UV), P. Moretto (3 ㅇ) (BMPC); same data 17.X.2015 (1 ㅇ) (BMPC); Togo, Fazao (hotel) [8 $\left.8^{\circ} 41^{\prime} \mathrm{N} 0^{\circ} 46^{\prime} \mathrm{E}\right]$ 3-4.VIII.2013 (UV), P. Moretto (1 3 ) (BMPC). 

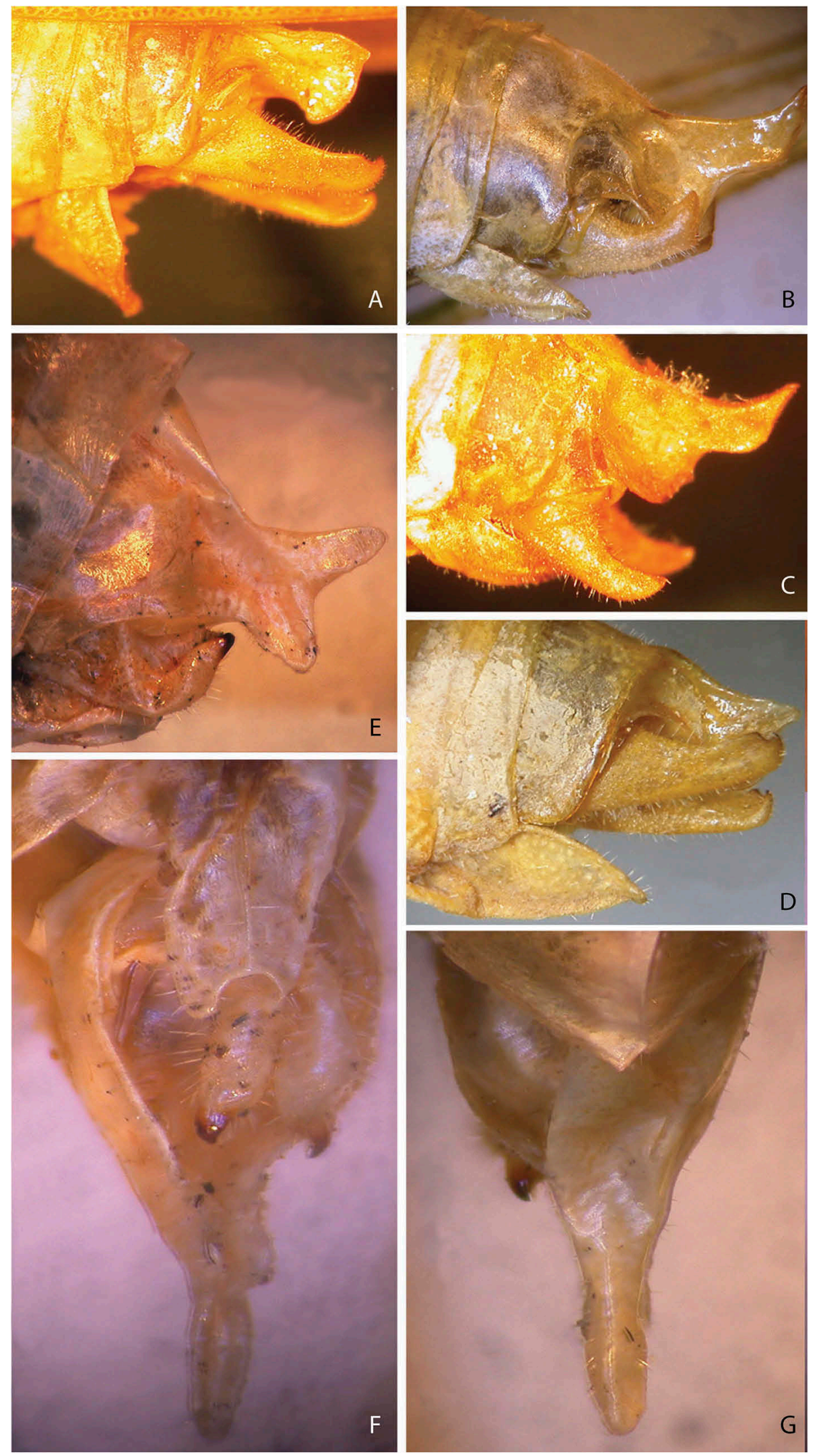

Figure 9. Lateral view of last abdominal segments of male. A, Eurycorypha laticercis Chopard. B, E. stylata Stål. C, E. stenophthalma Chopard. D, E. darlingi Uvarov. E, E. specularia $\mathbf{n}$. sp. F, G, E. specularia $\mathbf{n}$. sp.: F, dorsal view of last abdominal segments; G, subgenital plate and cerci. 
Remarks. Eurycorypha klaptoczi was described by Karny (1917) on a female from Guinea (West Africa), characterized by a short and strongly up-curved ovipositor, more or less as long as the pronotum and shorter than the fore tibiae, subgenital plate triangular. It is a large sized species. The following species of Eurycorypha were described on the female sex only; all of them are different from the female of E. klaptoczi. E. adicra Karsch, 1892 from Cameroon has a robust ovipositor, E. brevicollis Stål, 1876 from Namibia has a short pronotum and ovipositor; E. brevipennis Karsch, 1889 from Madagascar has a wrinkled pronotum with definite margins, wings rather short and very oval; differences from E. flavescens are above described; $E$. montana Sjösted, 1902 from Cameroon has a rather long ovipositor and the apex of subgenital plate is concave; $E$. mutica Karsch, 1891 from Cameroon has rather long and crenulated ovipositor, the subgenital plate triangular, apically straight, and longitudinally concave on the centre; E. zebrata Bruner, 1920 is a species of large size $(30 \mathrm{~mm})$, and has tegmina rather oval with vertical sinuous evident veinlets.

Description of male. Species of medium size. Green, legs yellowish.

Head typical of the genus, eyes oval, fastigium of vertex wide, ca. three times as wide as scapus. Frontogenal carinae poorly developed. Antennae long, green.

Pronotum flat, concave on the fore margin and rounded on the hind margin. Lateral carinae distinct, humeral excision anteriorly well-developed, its integuments wrinkled.

Both pairs of wings well-developed. Tegmina oval, rounded at tips, about 3.3-3.7 times longer than wide. Posterior wings longer than tegmina.

Fore coxae armed with one spine, fore tibiae with open tympana, fore femora with 3 inner ventral spines, fore tibiae with 4-5 spines on inner and on outer ventral margins; mid femora with $2-3$ outer ventral spines, mid tibiae with 6-7 inner and outer ventral spines; hind femora with 6-7 inner and outer ventral spines.

Last abdominal tergite modified, ending with a protrusion, whose surface is superiorly sulcate, with two appendices, one up-curved with two divergent flat apices, above a little rounded, below concave, the other down-curved, laterally compressed and sulcate on the upper surface, with two flat lateral apices. Cerci stout and incurved, apically toothed (Figure 8A). Styli absent, subgenital plate long and narrow.

Measurements. Male. Body length: 19.4-26.6; pronotum length: 4.0-5.0; length of tegmina: 29.9-33.6; width of tegmina: $8.0-10.2$; length of hind femora: 15.0-17.0. Female [in brackets values after Karny (1917)]. Body length: 18.4-22.4 (20.0); pronotum length: 4.0-4.8 (4.8); length of tegmina: 28.3-31.6 (29.5); width of tegmina:
8.3-9.9 (9.0); length of hind femora: 14.6-17.0 (14.5); ovipositor: 4.6-5.4 (4.6).

Affinities. Characteristics of the last tergite of male are very peculiar, morphologically related to Eurycorypha stylata Stål, 1873 (Figure 9B) and E. specularia n. sp. (Figure 9A, 9F, 9G).

Distribution. Hitherto known from Guinea, it is here recorded for the first time from Ivory Coast, Burkina Faso and Togo. In some localities of Ivory Coast (Kolomabira, M' Banto, Kogo), Eurycorypha klaptoczi has been found together with E. flavescens.

\section{Eurycorypha specularia n. sp. (Figure 9E, 9F, 9G)}

Type material. Holotype: $\hat{\sigma}$, Zambia NW, Mulobezi [16 47'59's 2510'26'"E) 8-27.VIII.1988, P. Agnelli (MZUF). Paratype: 1 , same data (MZUF).

Description. Male. Species of small size, yellowish.

Head typical of the genus, eyes oval, fastigium of vertex wide, c. 3 times as wide as scapus. Fronto-genal carinae well developed. Antennae long, yellow.

Pronotum flat, anterior margin concave, posterior margin rounded. Lateral carinae distinct, humeral excision well-developed; integuments smooth.

Both pairs of wings well developed. Tegmina oval, rounded at tips, about 3.6 times longer than wide. Many transparent small cells on tegmina. Hind wings longer than tegmina. Stridulatory file $c .1 .0 \mathrm{~mm}$ long, a little curved, consisting of $c .65$ teeth, of which the central are bigger than the proximal and distal ones.

Fore coxae armed, fore tibiae with open tympana, fore femora with 3 inner ventral spines, fore tibiae with 5 spines on inner and on outer ventral margins; mid femora with 3 outer ventral spines, mid tibiae with 8 inner and outer ventral spines; hind femora with 8 inner and outer ventral black tipped spines.

Last abdominal tergite modified, ending with a protruding up-curved and laterally compressed appendix, and a down-curved, laterally compressed and inferiorly furrowed appendix, with two flat lateral apices. Cerci stout and up-curved, apically toothed (Figure 9E, 9G). Styli absent, subgenital plate long and narrow (Figure 9F).

Female. Same characters as the male, but tegmina 3 times longer than wide, hind femora with 9 spines, cerci conical, subgenital plate triangular and centrally furrowed, ovipositor gently up-curved.

Measurements. Male. Body length: 15.0; pronotum length: 4.0; length of tegmina: 25.0 ; width of tegmina: 6.9 ; length of hind femora: 12.1. Female. Body length: 15.5; pronotum length: 4.1; length of tegmina: 28.2; width of tegmina: 9.4; length of hind femora: 13.7 ; ovipositor: 4.8 . 
Etymology. After its characteristic small transparent cells (from Latin speculum) of tegmina.

Diagnosis. Small species, characterized by many small transparent cells on tegmina; the male has the last tergite modified, similar to that of medium-sized Eurycorypha stylata and E. klaptoczi.

Distribution. Actually known only from the type locality, on the North-West Zambia (southern Africa).

\section{Tribe Poreuomenini Brunner von Wattenwyl, 1878}

Poreuomena lamottei Chopard, 1954 (Figure 10A-10E)

Material examined. Ivory Coast, Azagny National Park [5 $\left.{ }^{\circ} 14^{\prime} \mathrm{N} \quad 4^{\circ} 52^{\prime} \mathrm{W}\right]$ 26.XI-1.XII.2015 (light trap), M. Aristophanous, P. Moretto, E. Ruzzier (3 d) $^{\text {(NHM) }}$; Ivory Coast, Taï National Park, Res. Station [0549'59'N 07020'32”W] 5-10.VII.2015 (light trap), M. Aristophanous, P. Moretto, E. Ruzzier ( 1 đ) (NHM).

Remarks. Characters of Poreuomena lamottei consent to identify it easily (Figure 11A-11E); the stridulatory file is arched and consists of $c .60$ teeth, of which $c .30$ big teeth in the distal part and $c .30$ smaller and evenly spaced teeth in proximal part (Figure 10B)
Distribution. Known from Guinea and Ghana (Chopard 1954b; Naskrecki 2009), it is newly reported from Ivory Coast.

\section{Tribe Tylopsidini Brunner von Wattenwyl, 1878 Tylopsis fissa Ragge, 1964}

Material examined. Malawi, Mubanga Forest [9 $9^{\circ} 47^{\prime} 44^{\prime \prime} \mathrm{S}$ $\left.33^{\circ} 19^{\prime} 17^{\prime \prime} \mathrm{E}\right) 1910$, Bayon (11 ô, 1 우) (MSNG); Kenya, Masai Mara National Park [1 ${ }^{\circ} 25^{\prime} 33^{\prime \prime} S$ 34 $\left.53^{\prime} 13^{\prime \prime E}\right)$ (1600 m) 11.VI.1994, L. Bartolozzi (1 đ̂) (MZUF).

Distribution. Previously known only from the type locality (Entebbe, Uganda) (Ragge 1964), the presence in Kenya and Malawi extends its distribution remarkably southwards.

\section{Tribe Catoptropterigini Massa, 2016 \\ Catoptropteryx extensipes Karsch, 1896}

Material examined. Nigeria, surroundings of Sapele

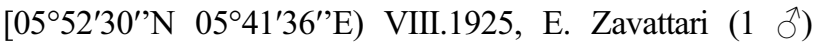
(MSNG).

Distribution. Catoptropteryx extensipes was previously known from Cameroon, Central African Republic, Sierra Leone, Liberia, Equatorial Guinea (Fernando Poo), Ivory

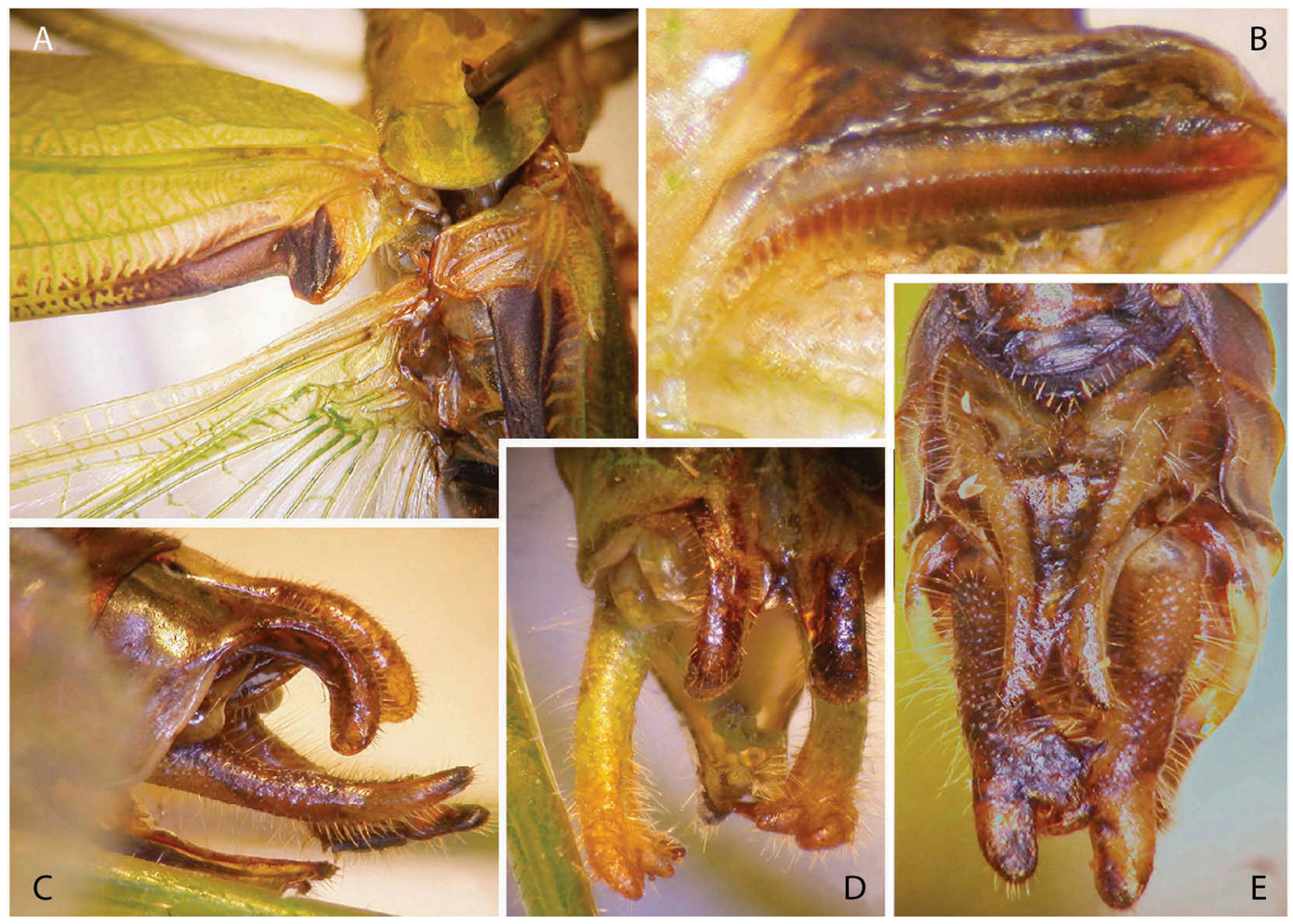

Figure 10. Poreuomena lamottei Chopard, $\hat{\jmath}$. A, Dorsal view of tegmina and stridulatory area. B, Stridulatory file. C, D, last abdominal segments and cerci: C, lateral view; D, dorsal view. E, Subgenital plate. 




Figure 11. Eucoptacra popovi n. sp., ô holotype. A, Habitus. B, lateral view of last abdominal segments. C, Details of left cercus. D, dorsolateral view of last abdominal segments.

Coast and Ghana (Karsch 1896; Huxley 1970, 1972; Naskrecki 2009; Massa 2013); it is newly recorded from Nigeria.

Phaneropterinae of uncertain tribe Mangomaloba latipennis Chopard, 1954
Material examined. Ivory Coast, Taï National Park, Res. Station [05'49'59'N 07 20'32”'W] 5-10.VII.2015 (light trap), M. Aristophanous, P. Moretto, E. Ruzzier (2 $\delta^{\lambda}, 1$ ) (NHM).

Distribution. Known from Guinea and Ghana (Chopard 1954b; Naskrecki 2009), it is newly reported from Ivory Coast. 
Family Acrididae MacLeay, 1821 Subfamily Coptacrinae Brunner von Wattenwyl, 1893 Eucoptacra popovi n. sp. (Figure 11A-11D)

Type material. Holotype: $\widehat{\partial}$, Gabon, Njolé $\left[0^{\circ} 07^{\prime} 10^{\prime \prime} \mathrm{S}\right.$ $11^{\circ} 59^{\prime} 55^{\prime \prime}$ ) XI-XII.1902, L. Fea (MSNG) (a label written by G. B. Popov in 1992 reports "Eucoptacra new species?").

Description of male. Figure 11A-11D. Light brown the first and the last two antennal segments, dark brown the others, pronotum light brown anteriorly, dark brown posteriorly, lateral lobes yellow with a central brown spot. Hind margins of tegmina lighter than the rest of the surface. Posterior femora dark brown with four wide yellow bands, the central band not reaching the lower keel. Inner surface and base of femora reddish, tibiae red with apex brown with 9 outer and 10 inner black tipped spines, rather hirsute.

Antennae much longer than head and pronotum together.

Pronotum with low median carina cut by three sulci, its posterior margin with right angle.

Tegmina with apices of the same length as folded hind femora.

Cerci deep basally with a short appendix as high as the base of cerci, similar to a sickle (Figure 11B, 11C). Supraanal plate with two central small spines, converging apically to a flat lobe (Figure 11D). Subgenital plate narrow apically. It was not possible to extract genitalia because of the poor state of the specimen.

Female unknown.

Diagnosis. Eucoptacra popovi n. sp. is easily distinguished from other species of the genus by its large size, red hind tibiae, very long antennae and sickle-shaped cerci.

Measurements. Male. Body length: 20.4; length of pronotum: 4.7; height of pronotum 4.2; length of tegmina: 15.6; length of hind femora: 12.7.

Etymology. This species is named after George Basil Popov (1922-1998), Russian-British entomologist, authority on desert locusts, who received the Lawrence of Arabia Memorial Medal (1995) from the Royal Society for Asian Affairs. In 1992, he identified as a probable new species the specimen here described.

Remarks. The genus Eucoptacra Bolívar, 1902 includes 29 species covering tropical Africa and Asia, of which 17 live in Africa. Dirsh (1966) presented a key to 14 of these species; later, another three species were described (E. spathulacauda Jago, 1966 from Ghana, E. granulata Mason, 1977 from Angola, and E. bicornis Baccetti, 2004 from Ivory Coast). Following Dirsh $(1966,1970)$ and Baccetti (2004), males are easily identified by the shape of cerci and colour of hind tibia. E. popovi n. sp. has red tibia and male cercus with apical appendix clearly different from those of all described species, included the three described after the publication of Dirsh (1966). In particular, E. spathulacauda and E. bicornis lie within the group of E. anguliflava (Karsch, 1893), widespread from West to East Africa, E. exigua Bolívar, 1912 from East Africa and E. basidens Chapman, 1960 from Ghana and Ivory Coast; instead, E. granulata lies within the group of E. similis Uvarov, 1953 from Angola, E. poecila Uvarov, 1939 from Angola, Democratic Republic of Congo and Rhodesia, and E. nana Uvarov, 1953 from Angola (Jago 1966; Dirsh 1966; Mason 1977; Baccetti 2004; Felix \& Massa 2016). There are two species with red tibiae, as in E. popovi n. sp.: E. gowdeyi Uvarov, 1923 from Uganda, Kenya and Tanzania, and E. turneri Miller, 1932 from South Africa, but the appendix of their cerci is very fine, like that of $E$. torquata Bolívar, 1912, E. exigua and $E$. spathulacauda, that however do not have a red hind tibia. Cerci of E. popovi n. sp. are very peculiar, because the appendix is as high as the base of cercus and is separated from it by a wide concavity; overall, the cercus is similar to a sickle. Finally, antennae are very long compared to other known species (however, E. basidens and E. bicornis have antennae as long as E. popovi n. sp.), and the size is large for the genus.

\section{Acknowledgements}

I am especially indebted to Mercedes Paris (Museo Nacional de Ciencias Naturales of Madrid), Michael Ohl (Museum für Naturkunde of Berlin), Suzanne Randolf and Harald Bruckner (NMW), Martin Fikáček (NMHP), Laure Desutter and Simon Poulain (Muséum national d'Histoire naturelle, Paris), Roberto Poggi, Maria Luisa Tavano and Giuliano Doria (MSNG), Luca Bartolozzi (MZUF) who facilitated the study of specimens preserved in their museums; to Corinna Bazelet (Department of Conservation Ecology and Entomology, Stellenbosch University) and Piotr Naskrecki (Museum of Comparative Zoology, Harvard University), for their suggestions; to Roberto Poggi (MSNG) and Haralabos Tsolakis (Department of Agriculture, Food and Forest Sciences, University of Palermo) for their advice on the Greek origin of the name Lamecosoma. I also thank very much Philippe Moretto, who kindly let me study the material collected during 2012-2016 in central and western African countries; Max Barclay (NHM) for facilitating the study and loan of Orthoptera collected by Marios Aristophanous, Enrico Ruzzier and P. Moretto in Ivory Coast. The collection and study of the material from the Ivory Coast was made possible thanks to the support of the African Natural History Research Trust (Hereford, UK) and Richard E. L. Smith. Collecting authorizations were obtained as follows: 019/UB/DSV2012 of 16.I.2012 from Bangui University, Central African Republic; 135/MESRS/DGRSIT/mo of 12. VI.2015, 238/MESRS/DGRSIT/mo of 13.X.2015, 040/ MESRS/DGRSIT/mo of 8.III.2016 from the Ministère de l'Enseignement Supérieur et de la Recherche Scientifique of Ivory Coast, and 0429/MINEDD/OIPR/DG of 14.VII.2016 and $0505 / \mathrm{MINEDD} / \mathrm{OIPR} / \mathrm{DG}$ of 18.VIII.2016 from the Ministère de l'Environnement et du Développement Durable of Ivory Coast. Finally, I thank the managers and contributors 
of the Orthoptera Species File (OSF, http://Orthoptera. SpeciesFile.org) for the great and useful work they carry out for orthopterists worldwide, and to Luca Picciau, who permitted the use of his photograph of Eurycorypha aequatorialis. Finally, I am very grateful to two anonymous referees, who gave many useful suggestions to improve a first manuscript, and John J. Borg for the English revision. This paper is dedicated to all curators of museum collections, who spend their life cataloguing, preserving and studying specimens collected in all the parts of the world, and allow taxonomists to carry out their research on this important evidence of biological diversity.

\section{Funding}

This research received support from the Synthesys Project, which was financed by European Community Research Infrastructure Action under the FP7 "Capacities" Programme at the following museums: Museo Nacional de Ciencias Naturales, Madrid (CSIC) [2013: ES-TAF-2438], Museum für Naturkunde, Berlin [2014: DE-TAF-4109], Naturhistorisches Museum, Vienna [2016: AT-TAF-5324], and National Museum of Natural History, Prague [2016: CZ-TAF-5559].

\section{References}

Baccetti B. 2004. Notulae Orthopterologicae. 53. Interesting reports from the Ivory Coast. Redia. 86:23-33.

Brunner von Wattenwyl C. 1878. Monographie der Phaneropteriden. Vienna; p. 401.

Chopard L. 1954a. Orthoptera-Ensifera from Kenya and Jubaland (ed. by L. Chopard \& D.K. Mc Kevan). Transactions of the Royal Entomological Society of London. 105:315-353.

Chopard L. 1954b. La réserve naturelle intégrale du Mont Nimba. II. Orthoptères Ensifères. Mémoires Institut français Afrique noire. 40:25-97.

Chopard L. 1958. Les Orthopteroides des Comores. Mémoires de l'Institut Scientifique de Madagascar, Série E Entomologie. 10:3-40.

Cigliano MM, Braun H, Eades DC, Otte D. 2016. Orthoptera Species File. Version 5.0/5.0. Available from: http:// Orthoptera.SpeciesFile.org

De Saussure H. 1899. Orthoptera. Wissenschaftliche Ergebnisse der Reisen in Madagaskar und Ostafrika in den Jahren 1889-95 von Dr. A. Voeltzkow. Abhandlungen der Senckenbergischen Naturforschenden Gesellschaft. 21:567-664.

Dirsh VM. 1966. Acridoidea of Angola 2. Publicações Culturais da Companhia de Diamantes de Angola. 74:310-527.

Dirsh VM. 1970. Acridoidea of the Congo (Orthoptera). Annales du Musée royal de l'Afrique centrale. 8:1-605.

Felix RPWH, Massa B. 2016. Orthoptera (Insecta: Tettigonioidea, Pyrgomorphoidea, Acridoidea) of Kafa Biosphere Reserve, Bale Mountains National Park and other areas of conservation interest in Ethiopia. Zootaxa. 4189:1-59.

Griffini A. 1908. Phasgonuridae africane del R. Museo di Storia Naturale di Bruxelles. 5 Phaneropteridae, pars 1. Mémoires de la Société entomologique de Belgique. 15:74-86.

Hadley A. 2008. Combine Z. Available from: http://www.hadle yweb.pwp.blueyonder.co.uk [cited 2009 February].

Heller K-G, Hemp C, Ingrisch S, Liu C. 2015. Acoustic communication in Phaneropterinae (Tettigonioidea) - a global review with some new data. Journal of Orthoptera Research. 24:7-18.
Hemp C. 2002. New Acrometopae from East Africa (Tettigoniidae: Phaneropterinae). Journal of Orthoptera Research. 11:67-76.

Hemp C. 2006. Two new species of Horatosphaga Schaum 1853 from the highlands of East Africa (Tettigoniidae: Phaneropterinae). Journal of Orthoptera Research. 15:251-259.

Hemp C. 2007. A new species of Horatosphaga Schaum, 1853 (Orthoptera: Tettigoniidae: Phaneropterinae) from savanna grasslands of Kenya. Journal of Orthoptera Research. 16:199-205.

Hemp C. 2013. Annotated list of Ensifera (Orthoptera) and further records on Caelifera (Orthoptera) of $\mathrm{Mt}$ Kilimanjaro, Tanzania. Zootaxa. 3613:301-342.

Huxley J. 1970. A revision of the genus Catoptropteryx Karsch (Orthoptera: Tettigoniidae). Bulletin of the British Museum of Natural History (Entomology). 24:129-170.

Huxley J. 1972. The female of Catoptropteryx extensipes Karsch with a note on C. guttatipes Karsch (Orthoptera, Tettigoniidae). The Entomologist's Monthly Magazine. 108:177-178.

[ICZN] International Commission on Zoological Nomenclature. 2012. International code of zoological nomenclature [Internet]. 4th ed. Available from: http://www.iczn.org/iczn/index.jsp

Jago ND. 1965/1966. Descriptions of new species of West African grasshoppers with taxonomic notes on some species recently mentioned in the literature (Orth. Acridoidea). Eos, Revista española de Entomología. 41:343-371.

Karny HH. 1917. Ergebnisse der Forschungsreise des Herrn Dr. Adalbert Klaptocz nach Französisch Guinea. Orthoptera und Oothecaria. Zoologische Jahrbücher. Abteilung für Systematik. Geographie und Biologie der Tiere. 40:119-146.

Karsch F. 1896. Neue Orthopteren aus dem tropischen Afrika. Stettiner entomologische Zeitung. 57:242-359.

Karsch FAF. 1888/1889. Orthopterologische Beiträge III. Berliner Entomologische Zeitschrift. 32:415-464.

Karsch FAF. 1891. Übersicht der von Dr. Paul Preuss auf der Barombi-Station in Kamerun gesammelten Locustodeen. Berliner Entomologische Zeitschrift. 36:317-346.

Karsch FAF. 1892. Verzeichniss der von Herrn Dr. Paul Preuss im Kamerungebirge erbeuteten Orthopteren. Berliner Entomologische Zeitschrift. 37:65-78.

Kirby WF. 1906. Orthoptera Saltatoria. Part I. (Achetidae et Phasgonuridae). A Synonymic Catalogue of Orthoptera (Orthoptera Saltatoria, Locustidae vel Acridiidae). 2:i-viii, $1-562$.

Malhi Y, Adu-Bredu S, Asare RA, Lewis SL, Mayaux P. 2013. African rainforests: past, present and future. Philosophical Transactions of the Royal Society B: Biological Sciences. 368:20120312.

Mason JB. 1977/1979. Acridoidea of south-west Angola (Orthoptera). Eos, Revista española de Entomología. 53:91-132.

Massa B. 2013. Diversity of leaf katydids (Orthoptera: Tettigoniidae: Phaneropterinae) of Dzanga-Ndoki National Park, Central African Republic, with selected records from other African countries. Journal of Orthoptera Research. 22:125-152.

Massa B. 2015a. New genera, species and records of Phaneropterinae (Orthoptera, Phaneropteridae) from subSaharan Africa. Zookeys. 472:77-102.

Massa B. 2015b. Taxonomy and distribution of some katydids (Orthoptera Tettigoniidae) from tropical Africa. Zookeys. 524:17-44.

Massa B. 2016. On some interesting African katydids (Orthoptera Tettigoniidae). Entomologia. 4:1-15.

Naskrecki P. 2009. A survey of Katydids (Insecta: Orthoptera: Tettigoniidae) of Ajenjua Bepo and Mamang River Forest 
Reserves, Eastern Region of Ghana. In: A rapid biological assessment of Ajenjua Bepo and Mamang River Forest Reserves, Ghana. RAP Bulletin Biological Assessment, Conservation International; p. 34-39.

Ragge DR. 1960a. The Acrometopae of the Ethiopian Region: a revision, with notes on the sexual dimorphism shown by the group (Orthoptera: Tettigoniidae). Bulletin of the British Museum (Natural History) Entomology. 8:269-333.

Ragge DR. 1960b. Further notes on the genus Phaneroptera Serville, with a revised key to the species (Orthoptera: Tettigoniidae). Proceedings of the Zoological Society of London. 134:237-250.

Ragge DR. 1961. Further notes on the genus Lamecosoma Ragge, with a description of a new species. Eos. 37:215-219.
Ragge DR. 1964. A revision of the genus Tylopsis Fieber (Orthoptera: Tettigoniidae). Bulletin of the British Museum (Natural History) Entomology. 15:297-322.

Ragge DR. 1980. A review of the African Phaneropterinae with open tympana (Orthoptera: Tettigoniidae). Bulletin British Museum (Natural History) Entomology. 40:1-192.

Ragge DR, Roy R. 1961. Le Parc National du Niokolo-koba VII. Orthoptera Tettigonioidea. Mémoires de l'Institut Français d'Afrique Noire. 62:105-107.

Sjöstedt Y. 1912. Zur Orthopterenfauna des Kamerungebirges. Arkiv för Zoologi. 7:1-30.

Walker F. 1869 Catalogue of the specimens of Dermaptera Saltatoria in the collection of the British Museum. Vol. 1, p. 1-224; Vol. 2, p. 225-423. 